\title{
Development and Evaluation of Control System for Microgrid Supplying Heat and Electricity
}

\author{
Yasuhiro Kojima Senior Member (Mitsubishi Electric Corp.) \\ Masanobu Koshio Member (Mitsubishi Electric Corp.) \\ Shizuka Nakamura Senior Member (Mitsubishi Electric Corp.)
}

Keywords: microgrid, load dispatching control, renewable energy, weather-dependent energy, dispersed generators

Photovoltaic (PV) and Wind Turbine (WT) generation systems are expected to offer solutions to reduce green house gases and become more widely used in the future. However, the chief technical drawback of using these kinds of weather-dependent generators is the difficulty of forecasting their output, which can have negative impacts on commercial grids if a large number of them are introduced. Thus, this problem may hinder the wider application of PV and WT generation systems. The Regional Power Grid with Renewable Energy Resources Project in Hachinohe, funded by New Enegy and Industrial Technology Development Organization, was launched to seek a solution to this problem.

The scope of the project is to develop, operate, and evaluate a Dispersed Renewable Energy Supply System with the ability to adapt the total energy output in response to changes in weather and demand. Such a system would reduce the impact that PV and WT generation systems have on commercial grids and allow the interconnection of more Dispersed Energy Resources (DER). In other words, the main objective of this project is to demonstrate an integrated energy management system, or a type of microgrid, as a new way of introducing DERs. The system has been in operation since October 2005 and will continue operation until March 2008. Through the project period, the data on power quality, system efficiency, operation cost, and environmental burden will be gathered and a cost-benefit analysis of the system will be undertaken.

In this paper, firstly we introduce the concept of microgrid for reducing negative impact of natural energy. Secondly we illustrate the structure of electric and thermal supply control system for microgrid. To ascertain the optimum solution, it is necessary to consider many variables including long-term factor such as efficient operation of thermal plant and short-term factor sush as flat control of tie-line power flow. Therefor we develop the control system consists of four stages; weekly operation planning, economic dispatching control, tie-line control and local frequency control. The operation planning and the economic dispatching control are formulated as combinatorial optimization problem including continuous valuable optimization problem, and a Problem Space Search method and QP method can be applied. For the tie-line control and frequency control, basically PID control theory can be applied. And finally demonstration results and evaluation results are shown. The Fig. 1 shows a example of the operation planning in a typical winter weekday. Proposed method can obtain appropriate operation plan for generators, battery, boilers and purshased power satisfying given constraints. Figure 2 shows the analysis result of relation between fluctuation cycle and strength as electirc power quality, that achieved by cooperative control of the economic dispatching control and the tie-line control in online operation phase. The figure shows that, in short cycle region, fluctuation of "demand" is dominant, on the other hand in long cycle region, impact of weatherdependent energy's fluctuation expands (noted as "PV"), and our proposed control system can effectively reduce impacts of weatherdependent energy fluctuation (noted as "controlled").

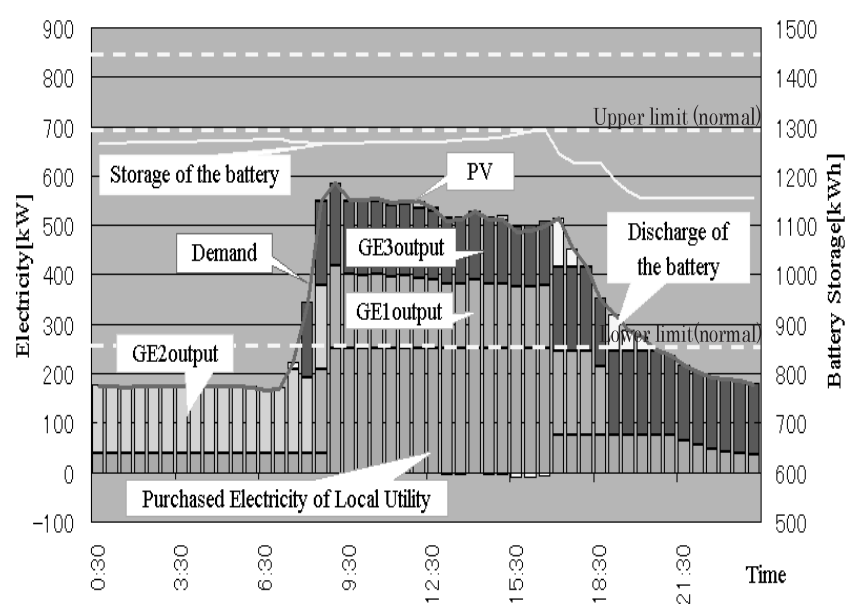

Fig. 1. Example of the operation planning

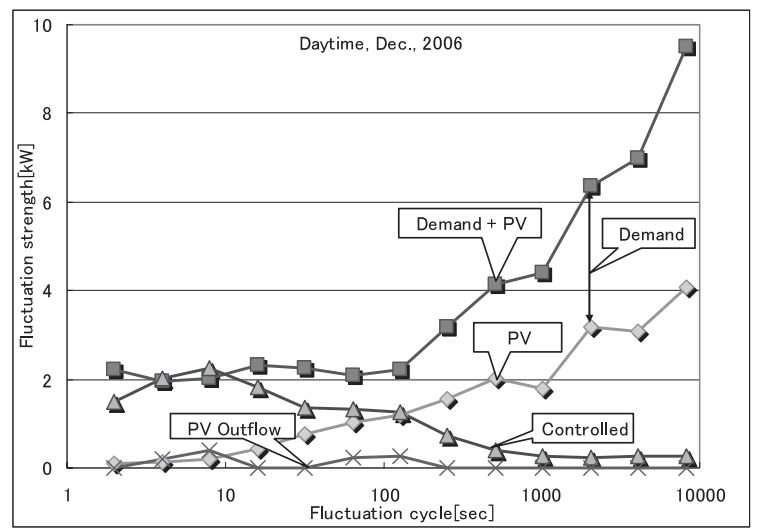

Fig. 2. Relation between fluctuation cycle and strength 


\title{
マイクログリッド向け需給制御機能の開発と実証検討
}

\author{
上級会員 小島 康弘* 正 員 古塩 正展** \\ 上級会員 中村 静香**
}

\section{Development and Evaluation of Control System for Microgrid Supplying Heat and Electricity}

Yasuhiro Kojima*, Senior Member, Masanobu Koshio**, Member, Shizuka Nakamura**, Senior Member

Photovoltaic (PV) and Wind Turbine (WT) generation systems are expected to offer solutions to reduce green house gases and become more widely used in the future. However, the chief technical drawback of using these kinds of weather-dependent generators is the difficulty of forecasting their output, which can have negative impacts on commercial grids if a large number of them are introduced. Thus, this problem may hinder the wider application of PV and WT generation systems. The Regional Power Grid with Renewable Energy Resources Project was launched to seek a solution to this problem.

The scope of the project is to develop, operate, and evaluate a Dispersed Renewable Energy Supply System with the ability to adapt the total energy output in response to changes in weather and demand. Such a system would reduce the impact that PV and WT generation systems have on commercial grids and allow the interconnection of more Dispersed Energy Resources (DER). In other words, the main objective of this project is to demonstrate an integrated energy management system, or a type of microgrid [1], as a new way of introducing DERs. The system has been in operation since October 2005 and will continue operation until March 2008. Through the project period, the data on power quality, system efficiency, operation cost, and environmental burden will be gathered and a cost-benefit analysis of the system will be undertaken.

In this paper, firstly we introduce the concept of microgrid for reducing negative impact of natural energy, and secondly illustrate the structure of electric and thermal supply control system for Microgrid, especially for the Hachinohe demonstration project. The control system consists of four stages; weekly operation planning, economic dispatching control, tie-line control and local frequency control. And finally demonstration results and evaluation results are shown.

キーワード：マイクログリッド，需給制御，自然エネルギー，再生可能エネルギー，分散型電源

Keywords: microgrid, demand and supply control, renewable energy, weather-dependent energy, dispersed generators

\section{1. はじめに}

近年, $\mathrm{CO}_{2}$ 削減など環境負荷低減の要求が高まっており, 燃料電池, バイオマス発電, 太陽光発電, 風力発電などの 再生可能エネルギーの開発・実用化が進められている。し かし, 太陽光, 風力などの自然エネルギーは, 出力が不安 定で予測制御も困難なため，今後大量の自然エネルギーが 商用系統と連系した場合には, 系統の安定性や信頼性に対

\footnotetext{
*三菱電機 (株) 先端技術総合研究所

₹ 661-8661 尼崎市塚口本町 8-1-1

Advanced Technology R\&D center, Mitsubishi Electric Corp.

8-1-1, Tsukaguchi-honmachi, Amagasaki 661-8661

**三菱電機（株）神戸製作所

₹ 100-8310 東京都千代田区丸の内 2-7-3

Kobe works, Mitsubishi Electric Corp.

2-7-3, Marunouchi, Chiyoda-ku, Tokyo 100-8310
}

して悪影響が及ぶことが懸念されている。一方，これまで 大量の電気の安定供給を目的として大規模集中型発電所が 整備されてきたが, 計画から運用開始までのリードタイム が長く, また大規模発電所の立地条件を満足する地域は需 要地から遠い場所が多いため熱回収効率まで含めた総合工 ネルギー効率の向上には限界があった。このため, 需要家 側で電熱併給可能な分散型電源の導入が進んでいるが，系 統運用側から見ればこれらも不可観測・不可制御であり大 量導入による影響が懸念される。これらの課題を解決する 手段の一つとして，近年マイクログリッドという考え方が 注目されている。マイクログリッドとは, 分散型電源と需 要設備から構成される小規模系統を商用系統と一点で連系, あるいは商用系統から独立させて, この中で電熱需給制御 を行うことが可能なシステムのことをさす(1)(2)。 これまでに，マイクログリッドに関しては，たとえば分散 
型電源の需給調整手法の検討 (3), 電力変動抑制効果に関す る検討 ${ }^{(4)}$ などの理論検討や，世界各国でマイクログリッド の実証試験が行われている ${ }^{(5)}$ が，自然エネルギー変動抑制 効果に関して実際の制御機器を用いた実証試験結果の報告 は少ない。このような背景のもと，我々はマイクログリッ ドのための需給制御技術の開発と実証試験による検証を実 施している ${ }^{(6) \sim(8)}$ 。そこで本論文では，まずマイクログリッ ドによる自然エネルギー出力変動の抑制と分散型電源の運 用の考え方と，われわれの構築したマイクログリッド実証 試験設備の概要について説明する。次に自然エネルギーの 出力変動安定化とシステムの経済運用を目的としたマイク ログリッド向けの 4 階層需給制御機能について説明する。 最後にマイクログリッド実証試験の結果について，提案す るマイクログリッド向け需給制御の効果を自然エネルギー 出力変動抑制の観点から評価し，有効性を示す。

\section{2. マイクログリッドと需給制御}

〈2·1〉 マイクログリッドの構成一般的にマイクロ グリッドの構成要素として，ガスエンジン・燃料電池等の コージェネレーション電熱源, 太陽光発電・風力発電・バイ オマスボイラ等の再生可能エネルギー電熱源ならびに電熱 需要を考える。このうち, 太陽光発電や風力発電について は出力を精度よく予測する事は困難であるが，エネルギー 効率の面からは出来るだけ有効に利用する必要がある。こ れらの電熱源を用いて負荷設備の需要に対して経済的かつ 安定的に運用するためには，二次電池や蓄熱槽等の電熱貯 蔵設備の利用が不可欠となる。これらの設備間は配電線や 熱パイプラインで接続されるとともに，通信網を介したシ ステム化が必要である。

〈2·2〉 八戸マイクログリッドの概要＼cjkstart我々は, NEDO 技術開発機構の委託事業「新エネルギー等地域集中実証研 究」における「八戸市水の流れを電気で返すプロジェクト」 においてマイクログリッド向け需給制御システムを開発し, 2005 年 10 月から実証試験を実施している。

実証試験における機器構成を表 1 に，エネルギー供給の 概略を図 2 に示す。総電力需要 $610[\mathrm{~kW}]$ に対し，電源は総 供給力 $710[\mathrm{~kW}$ のうち自然エネルギー $100[\mathrm{~kW} （ 2007$ 年

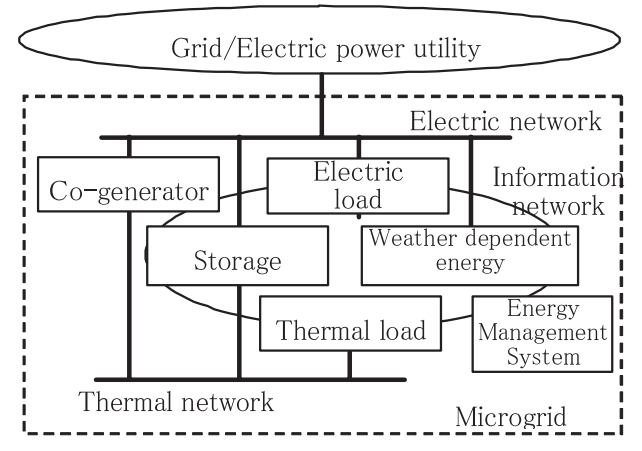

図 1 マイクログリッドの構成

Fig. 1. Structure of microgrid system.
3 月以降はさらに $\mathrm{PV}$ を $50[\mathrm{~kW}]$ 増設, 図表中*部）を含 む機器構成となっている。また, 熱需要に対しては消化ガ スボイラ，木屑ボイラ，ならびにガスエンジンの排ガスボ イラにより熱供給を行う。実証試験に導入したエネルギー (燃料) は, 太陽光, 風力, 下水污泥消化ガス, 木屑（バー ク）の 4 種類であり，いずれも再生可能エネルギーである。

〈2·3〉需給制御機能 マイクログリッドを経済的に 運転するためには，需要の変動以外に自然エネルギーや場 合によっては昼夜間の負荷シフト等も考慮して分散型電源 の運転を適切に行う必要がある。需要には, 電力需要と熱 需要が存在するが，分散型電源は電熱併給が一般的であり 両者を分離して考える事はできない。このため, 地域をま たいだ融通が困難な熱のバランスを主として考え, 電力に ついては商用系統から買電 (もしくは売電) することが一

表 1 実証試験の設備一覧

Table 1. Equipments list of demonstration project.

\begin{tabular}{|c|c|c|c|}
\hline & Equipment & Rating & Remarks \\
\hline \multirow{6}{*}{$\begin{array}{l}\text { Electric } \\
\text { power } \\
\text { supply }\end{array}$} & Gas engine & $170[\mathrm{~kW}] \times 3$ & Digestive gas \\
\hline & Battery & $\begin{array}{l} \pm 100[\mathrm{~kW}] \\
1440[\mathrm{kWh}]\end{array}$ & Lead-Acid \\
\hline & $\mathrm{PV}(1) *$ & $50[\mathrm{~kW}]$ & \\
\hline & $\mathrm{PV}(2)$ & $10[\mathrm{~kW}] \times 3$ & \\
\hline & WT(1) & $8[\mathrm{~kW}] \times 2$ & \\
\hline & WT(2) & $4[\mathrm{~kW}]$ & \\
\hline \multirow{2}{*}{$\begin{array}{c}\text { Heat } \\
\text { supply }\end{array}$} & Gas boiler & $4[\mathrm{t} / \mathrm{h}]$ & Digestive gas \\
\hline & Wood boiler & $1[\mathrm{t} / \mathrm{h}]$ & Woody debris \\
\hline $\begin{array}{l}\text { Electric } \\
\text { power } \\
\text { demand }\end{array}$ & $\begin{array}{l}\text { City hall, } \\
\text { Office Bldg, } \\
\text { Schools }\end{array}$ & $610 \quad[\mathrm{~kW}]$ & \\
\hline $\begin{array}{c}\text { Heat } \\
\text { demand }\end{array}$ & $\begin{array}{l}\text { Digester } \\
\text { chamber }\end{array}$ & $10[\mathrm{Gcal} / \mathrm{day}]$ & \\
\hline
\end{tabular}

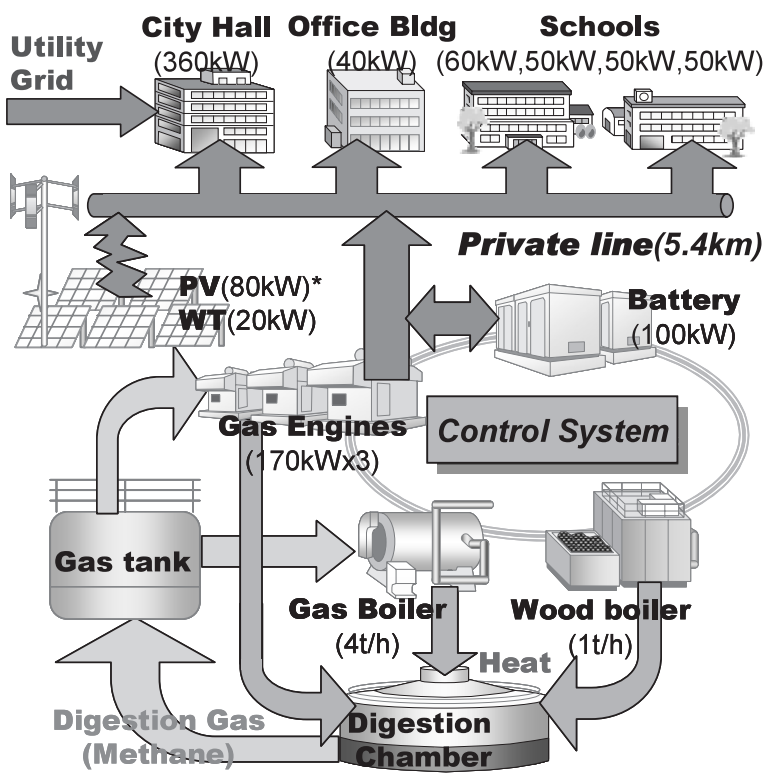

図 2 八戸プロジェクトにおけるエネルギー供給 の概念図

Fig. 2. Schematic view of energy supply in Hachinohe project. 
般的である。このように, 各種の運用制約のもとで最適電 熱利用を行うことを最適経済負荷配分と呼ぶ。

また，マイクログリッドが商用系統と連系されていれば， 予測・制御が困難な自然エネルギーの出力変動は, 商用系 統が吸収する。しかし，今後このような自然エネルギーが 増大すると，商用系統に与える影響は無視できなくなる。 また，商用系統と連系しない運用形態（非常時や離島）を 考えれば, 周波数を一定に保つためには電力の需要と供給 が一致している必要がある。このような制御を需給バラン

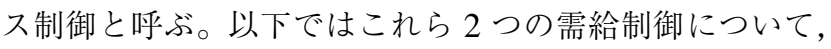
八戸プロジェクトにおける実証試験で開発したマイクログ リッド向け需給制御機能の実現方法について記述する。

\section{3. 最適経済負荷配分}

〈3・1 基本的な考え方 マイクログリッド内の電熱 需要に対して, 各種制約のもと経済性・環境性等を考慮し た評価関数值が最小となるよう, 電熱源ならびに電熱貯蔵 設備を最適に制御する。この制御には, 燃料や蓄電設備な ど 1 週間程度の効率運用を考慮するべき項目と, 時々刻々 変化する電力需給バランスなど, 時間レンジの異なる項目 が混在している。このような全ての項目を必要となる最も 短い計算刻みで最適化する事は計算効率が悪いため, 電熱 併給の計画は 30 分刻み 1 週間分の計画を毎日立案し, 時々 刻々の計画からのずれを数分周期で補正制御するよう最適 経済負荷配分問題を階層化する。本稿では，前者を需給運 用計画，後者を経済負荷配分制御と呼ぶ。

$\langle\mathbf{3 \cdot 2 \rangle}$ 需給運用計画 需給運用計画では, 過去の実 績㧍よび気象予報情報から求めた電熱需要予測に対して,

1 週間先までを考慮した電熱需給の最適計画（時間刻み 30 分）を立案する。計画立案にあたっては, 需給バランス, 燃料（消化ガス, 木屑）の消費量, 蓄電設備容量, ならび に需要予測誤差や自然エネルギーに対する变動対応予備力 量を制約条件として, 電熱源の起動停止状態, 出力調整可 能な電熱源の出力値, 抢よび商用系統との連系線潮流（買 電量·売電量) を, 目的関数 (燃料コストや環境コス卜等) が最小となるよう決定する。以下に需給運用計画で扱う最 適化問題を定式化する。

【目的関数】

$$
\begin{aligned}
& \min \left(a F_{1}+b F_{2}\right) \\
& F_{1}=(\text { 制御対象機器の経済コスト }+ \text { 買電経済コスト }) \\
& F_{2}=(\text { 制御対象機器の環境コスト }+ \text { 買電環境コスト })
\end{aligned}
$$

【制御変数】

(1) 制御対象機器の時間帯別運転状態（離散值）

(2) 制御対象機器の時間带別出力 (連続值)

(3) 連系点に扮ける時間带別買電量 (連続值)

【制約条件】(優先順位順)

(4) 制御变数(2)(3)の上下限制約

(5) 最短運転/停止時間制約

(6) 起動/停止時パターン制約
(7) 污泥消化槽温度上下限制約

(8) 污泥消化槽熱供給日量制約

(9) 燃料消費量制約

(10) 燃料貯蔵設備容量制約

(11) 蓄電電力量制約

(12) 電力需給バランス制約

(13) 買電量設定変更回数

(14) 運転予備力制約

ここで, 目的関数における $F_{1}$ は燃料費 (木屑購入費), 起 動費 (助燃用重油), 買電の経済コスト, $F_{2}$ は $\mathrm{CO}_{2}$ 排出量 などの環境コストに関する目的関数であり， $F_{1}$ と $F_{2}$ にそ れぞれ重みを付けて，その合計值を 1 つの目的関数として 最小化する。買電単価は時間带ごとに設定可能としている が, 本実証試験では契約の実態に合わせて昼夜一定とした。 (1)はガスエンジンの運転/停止状態, 二次電池の充放電/均等 充電状態, 消化ガスボイラの運転/停止状態, 木屑ボイラの 停止/弱燃焼/中燃焼/強燃焼状態，また(2)はガスエンジン・二 次電池の出力である。上下限值(4)ついて, 二次電池出力 (2)上下限制約は通常運転時と均等充電時で異なる。また 買電量(3の上下限制約は，マイクログリッドから系統への 逆潮流が発生しないための下限制約と自営線に系統からの 電力が流机込まないための上限制約を設定した。(5)，(6は 設備毎に(1)状態遷移に関連する制約条件である。発生し た熱は污泥消化槽の加温に使われるが，8で与えられる一 日に決められた熱量の投入制約とともに各時間带で温度上 下限制約(7を考慮した。ガス使用量はガスエンジン, ガス ボイラの出力から従属的に決まるが, 本システムでは消化 ガスの日発生量予測值に対する使用量の制約(9ならびにガ スタンクの上下限制約(11)を考慮する。蓄電池の蓄電残量は 蓄電池出力(2) と充放電効率から従属的に決まり, その上下 限制約が(11)である。ここで対象期間の最終蓄電量は初期蓄 電量と等しいという制約を与えた。(13)は連系点潮流を極力 一定にするために買電量変更回数を 1 日 2 回とする制約条 件を設定可能とした。運転予備力四は, 需要予測の誤差考 慮分として需要予測の $10 \%$, 自然エネルギー変動分とし て, 自然エネルギー出力が 0 になる場合と, 季節・時間带 ごとの想定最大出力になる場合とを考慮し, これらの変動 を変動吸収可能なように設定している。

この需給運用計画問題は, 制御対象機器の状態を決定す る離散值問題と, 運転中機器の出力値および買電量を決定 する連続値問題からなる混合整数計画問題となる。離散值 問題の解法としてタブサーチ法を取り入れた問題空間探索 法(9)を適用し, 各機器の運転状態の評価は, 各機器の制御 量（連続值）を二次計画法により最適化することにより行 う。なお，制約条件に対する違反量は，優先順位に応じた 係数を乗じてペナルティとして目的関数に加算した。

$\langle\mathbf{3} \cdot \mathbf{3}\rangle$ 経済負荷配分制御 経済負荷配分制御 $(\mathrm{EDC})$ は, 3 分周期で将来 2 時間先までの需給バランスを考慮し た最適化計算（時間刻み 3 分）を実施し，ガスエンジンの 起動停止と出力, 蓄電池の充放電量を制御する。これを需 
給運用計画と同様に以下のように最適化問題として定式化 する。

\section{【目的関数】}

$$
\begin{aligned}
& \min \left(a F_{1}+b F_{2}\right) \\
& F_{1}=(\text { 制御対象機器の経済コスト }) \\
& F_{2}=(\text { 制御対象機器の環境コスト })
\end{aligned}
$$

\section{【制御变数】}

(1) 制御対象機器の時間带別運転状態

(2) 制御対象機器の時間带別出力

【制約条件】(優先順位順)

(3) 制御対象機器出力上下限制約

(4) 最短運転/停止時間制約

(5) 起動/停止時パターン制約

(6) 污泥消化槽温度上下限制約（最終時刻）

(7) 燃料消費量制約（最終時刻）

(8) 蓄電電力量制約（最終時刻）

(9) 電力需給バランス制約

(10) 運転予備力制約

ここで，買電量については前日通告運転を前提としたため 制御変数から除外する。1 週間の長期トレンドを考慮して 最適化すべき項目（燃料消費計画，熱需要供給計画，蓄電 池運用計画）については，前述の 1 週間を対象とした需給 運用計画で得られた当該期間最終時点の計画值を制約条件 (6)(7)として与えた。この問題についても, 運用計画問題 と同じく組合せ最適化手法と連続值最適化手法を適用する。

\section{4. 需給バランス制御}

〈4・1 連系点電力制御 3 分周期で動作する経済負 荷配分に対して，本機能では，需要変動および自然エネル ギー変動によるアンバランスを補正するために，1 秒周期 で連系点潮流の一定制御を行う。また，この 1 秒周期制御 の累計誤差を吸収するため，6 分を目安とした同時同量制 御も合わせて行なっている。

同時同量制御には，PPS の同時同量制御の考え方を 6 分 に短縮しその時間带の中で電力量を合わせる方法と，制御 周期ごとに制御誤差の 6 分移動平均を評価する方法がある。 前者は例えば 6 分間の前半で発生したアンバランス量を後 半で調整して総量をあわせるような場合, 自然エネルギー の変動周期によっては変動が拡大される可能性がある。こ のため本実証試験では後者の移動平均方式を採用した。本 実証試験では，需給バランスの目標制御精度として，前日 計画買電量と連系点電力実績値の 6 分間移動平均誤差を, 各時刻の需要の $3 \%$ 以内に抑える事とした。

連系点電力制御は, 図 3 に示すように, 目標値と実績の 偏差に対して比例積分制御を 1 秒周期で実施し，EDC 指 令值に対する補正指令として扱った。制御対象の応答特性 （蓄電池は 1 秒）と伝送遅延（最大 2 秒）を考慮して比例制 御は $\mathrm{T} 1=10$ 秒程度の一次遅れフィル夕, 積分制御は長周 期の需給バランス制御には EDC が対応することから $\mathrm{T} 2=$

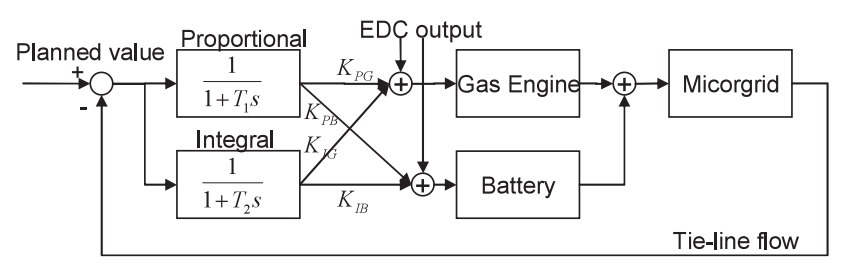

図 3 連系点電力制御と経済負荷配分制御

Fig. 3. Tie-line control and economic dispatching control.

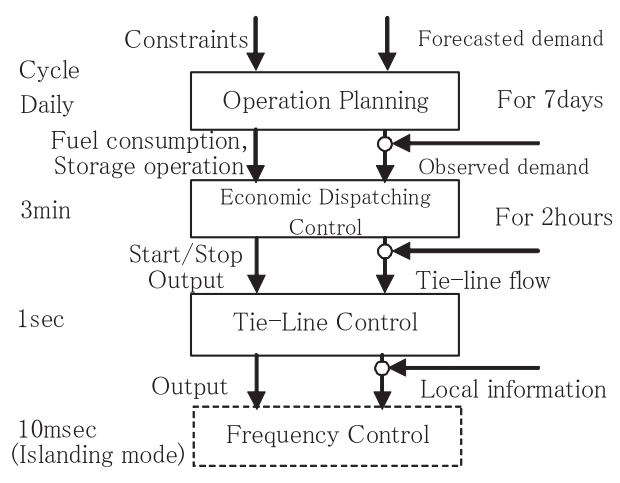

図 4 階層型需給制御方式

Fig. 4. Hierarchy of load dispatching control.

6 分の一次遅れフィルタで実現した。各制御対象機器のゲ イン $K$ は, 制御対象の応答特性を考慮して, 応答の速い二 次電池は主として比例制御を, ガスエンジン（時定数約 1 分）は主として積分制御を分担させるようを決定した。こ れに対して, 経済負荷配分制御では計算タイミングにおけ る各制御対象機器の出力合計值を, 経済性を考慮して再配 分することで，経済性と応答性の両方を満足する制御が可 能となる。

〈4·2 $\rangle$ ローカル周波数制御 マイクログリッドを商 用系統に連系している場合, マイクログリッド内の有効 · 無効電力の過不足は系統から供給されるため周波数問題や 電圧問題は発生しないが, 非常時や離島での自立運用を考 えるとこれらの問題についても検討する必要がある。例え ば，本実証試験で採用した $200 \mathrm{~kW}$ 級ガスエンジンの慣性 定数は小さく, $100 \mathrm{~kW}$ の需給アンバランスが 0.1 秒継続す れば，周波数変動は最大約 $3 \mathrm{~Hz}$ に及ぶ。すなわち連系時は 問題にならない需要変動が自立運転系統では問題となる。

このような自立運転系統時の周波数変動を抑えるために, 蓄電池のインバータを $10 \mathrm{msec}$ 周期で高速に制御する方式 を採用した。本稿では，この制御をローカル周波数制御と 呼ぶ。自立運転時は, 本ローカル周波数制御が微分制御と 比例制御の一部を担い, 中央では連系点電力制御が周波数 制御として比例制御の一部と積分制御を担うことで, 応答 性と制御精度の両立を実現している ${ }^{(10)}$ 。

以上で述べた需給運用計画, 経済負荷配分制御, 連系点 電力制御，ならびにローカル制御の 4 階層で構成される需 給制御機能を図 4 に示す。 


\section{5. 実証試験による検証}

本章では，八戸マイクログリッドのおける需給運用計画 結果, 需要変動や自然エネルギーの出力変動に対する負荷 追従特性について, 実証試験中に得られた結果を報告する。 なお, 今回の実証期間中では目的関数としては $F_{1}$ : 経済コ ストのみを用いている。

$\langle\mathbf{5} \cdot \mathbf{1}\rangle$ 需給運用計画需給運用計画における計画対 象期間は将来 7 日先までであるが，ここではそのうち経済 負荷配分制御に引継ぐ翌日の 1 日分に着目して計画結果を 考察する。図 5 に電力需給計画を, 図 6 に熱需給計画を示 す（いずれも (a) 冬季平日，(b) 春季平日，(c) 夏季平日で ある)。

図 5, 図 6(a) の冬季平日の需給計画では, 冬季は電力需

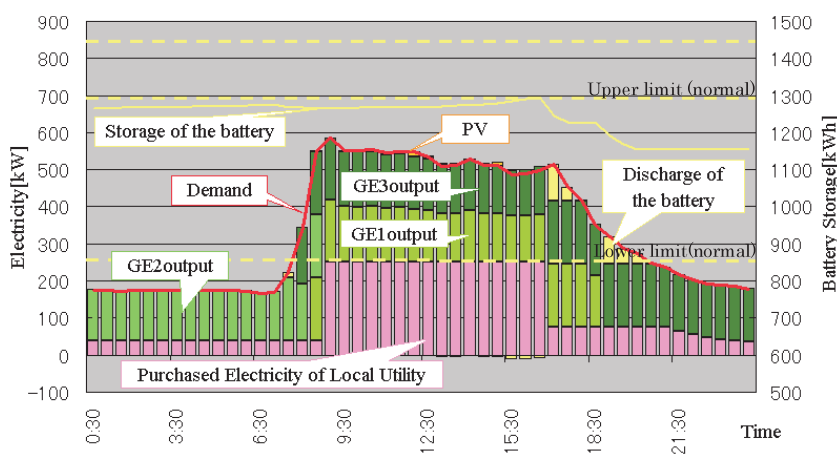

(a) 冬季平日 (Weekday, Winter)

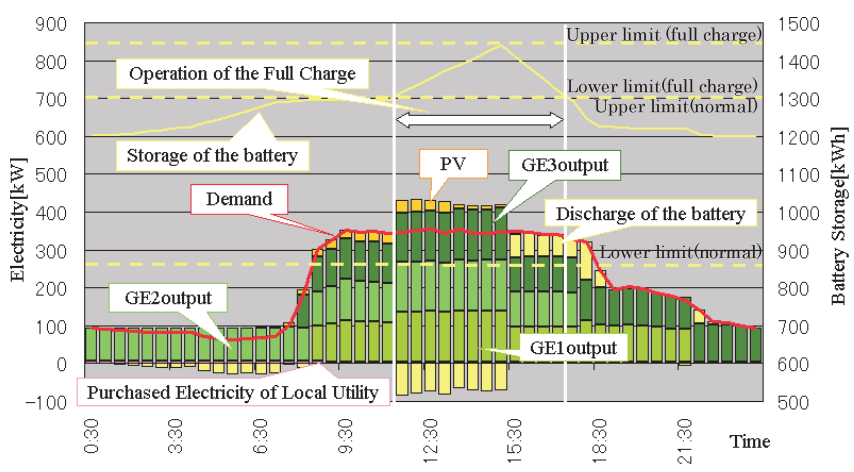

(b) 春季平日 （均等充電日） (Weekday, Spring, Full-charge)

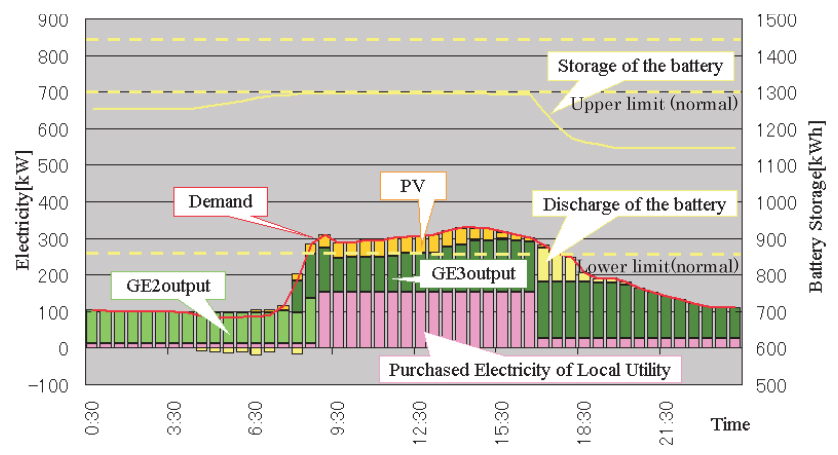

(c) 夏季平日 (木屑停止) (Weekday, Summer, Wood boiler stop)

図 5 電力需給計画例

Fig. 5. Examples of the electric power operation planning.
要が大きく, 電力需要の大半をガスエンジンで供給するに は燃料 (消化ガス) が不足するため, 昼間帯に買電量を増 やした計画が得られている。買電量の変更回数は 2 回に設 定しているが，優先順位の高い燃料制約を満足するために 21 時以降の買電量が徐々に変化している。二次電池につい ては充放電ロスが存在するため, 運転効率面からは充放電 を抑えた計画となることが望まれる。計画では二次電池が 18 時前後に放電する計画が得られているが，ガスエンジン の部分負荷効率, 買電量一定制約, 燃料制約, 蓄電量制約 を考慮した妥当な計画值となっている。なお，ガスエンジ ン 3 台は同一特性であり運転時間の均等化を図るために起 動停止優先順位を日々変更している。この結果, 早朝は 2 号機のみが運転しているが，3台運転から 2 台運転となっ た時点で 2 号機を優先して止める運用となっている。

熱需給計画に関しては, 冬季の熱需要は電力需要と同様

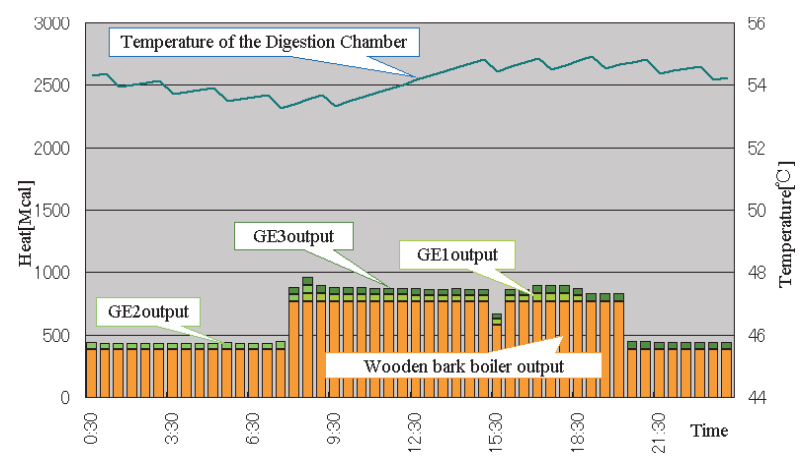

(a) 冬季平日 (Weekday, Winter)

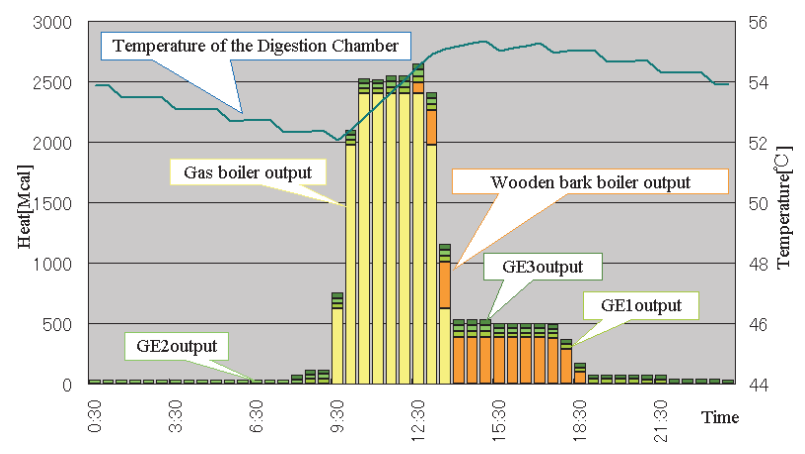

(b) 春季平日 (均等充電日) (Weekday, Spring, Full-charge)

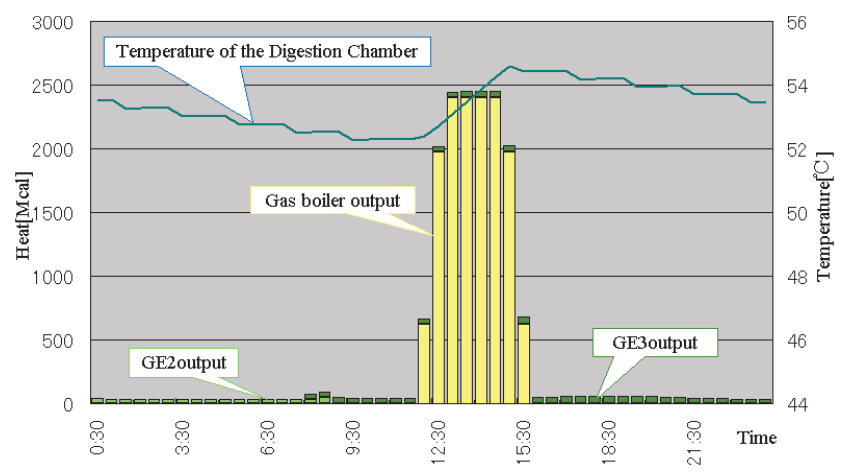

(c) 夏季平日 (木屑停止) (Weekday, Summer, Wood boiler stop)

図 6 熱需給計画例

Fig. 6. Examples of the thermal operation planning. 
に大きくなるが，消化ガスを電力供給に使用するため熱供 給は主に木屑ボイラで行う計画が得られている。また, 熱 需給計画では，ガスエンジンの排熱を利用してボイラへの 給水予熱を行うため，ガスエンジンの運転台数が増加する 昼間帯に多くの熱供給を行い，消化槽温度が制約範囲の 52 度〜55.5 度の範囲となる計画が得られている。

図 5, 図 6 の (b) の春季平日の需給計画は, 鉛蓄電池の 均等充電を実施する日の計画例である。春季は冬季に比べ て電力需要が少なく，消化ガスの残量に余裕が生まれるた め, 電力需給計画では買電量を下限值一定とした計画が立 案されている。また，均等充電期間に必要な蓄電量もガス エンジンの出力増発で対応できている。熱需給計画につい
ては, 主に燃料費が発生しない消化ガスボイラにより熱供 給を行い，不足分を木屑ボイラによる熱供給で補う計画が 得られていることが分かる。

図 5, 図 6(c) の夏季平日の需給計画は, 木屑ボイラが定 期点検で停止する日の計画例である。夏季も春季と同様, 冬季に比べ電力需要が小さい。また, 夏季は一年を通じて 最も熱需要が小さい時期となる。木屑ボイラの定期点検停 止により，熱供給を消化ガスボイラだけで行う必要がある ため, 消化ガスの貯蔵設備容量制約を満足するよう, 買電 量を増やした電力需給計画が得られている。

〈5・2〉 オンラインの自動需給制御オンラインでは, 経済負荷配分制御と連系点電力制御の協調制御による自動需

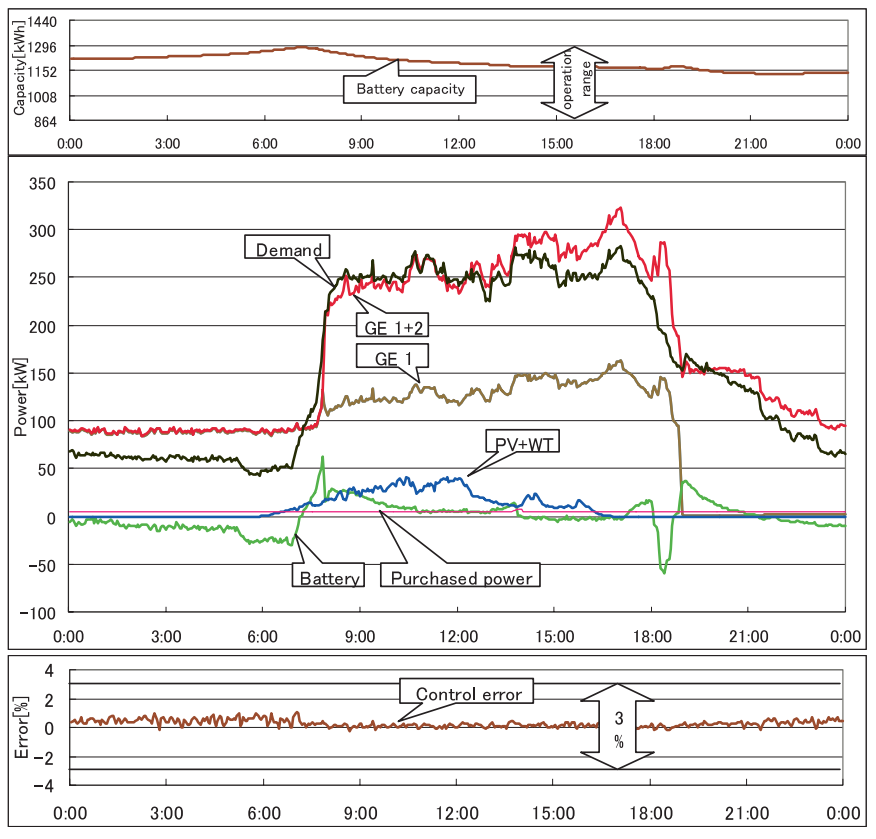

(a) 初冬平日 (weekday, early winter)

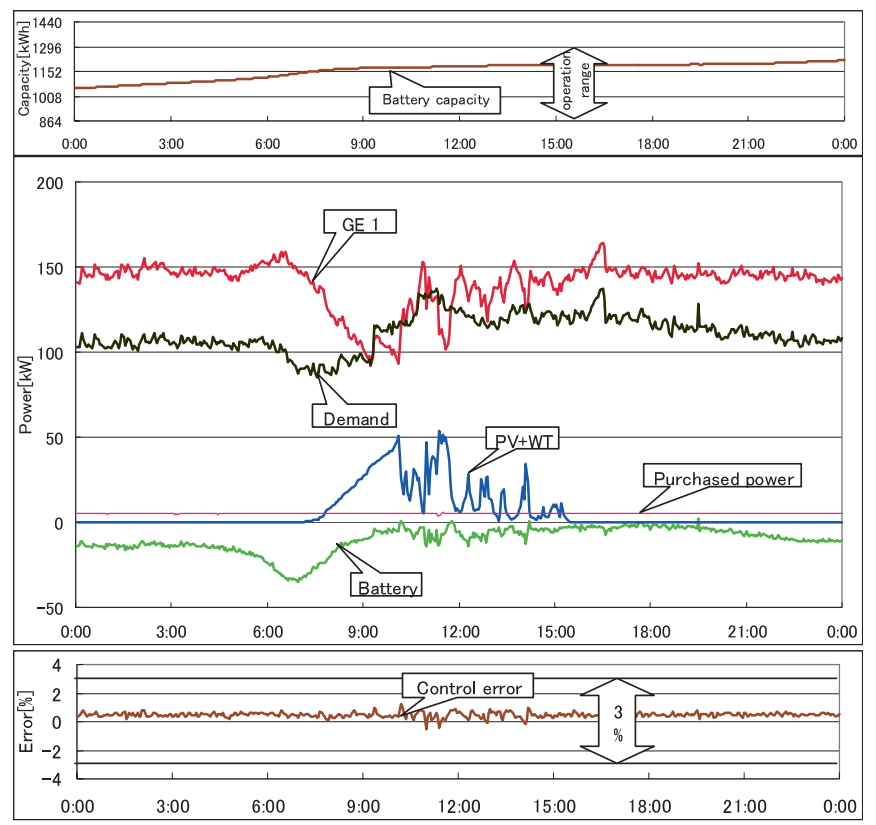

(b) 初冬休日 (holiday, early winter)

図 7 制御結果例

Fig. 7. Examples of control result.

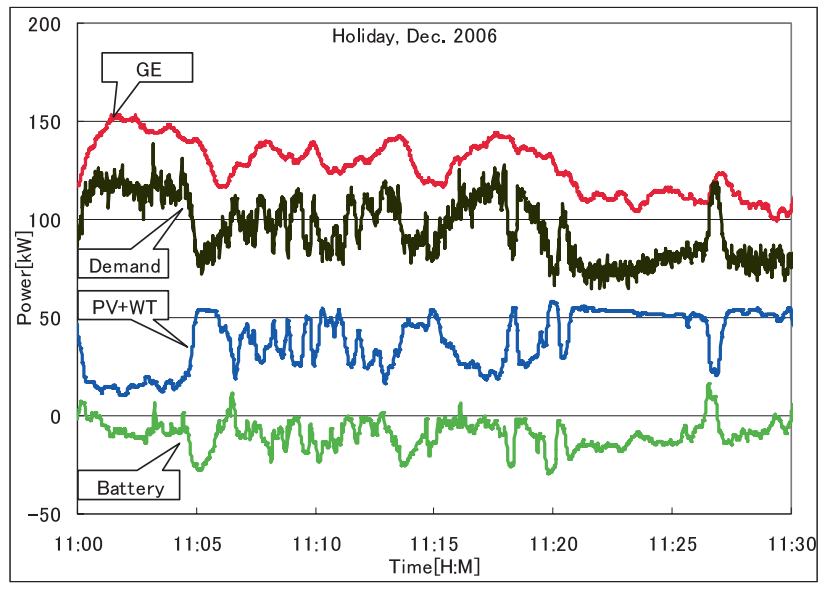

図 8 急激な負荷変動への追従

Fig. 8. Control result with rapid demand change.

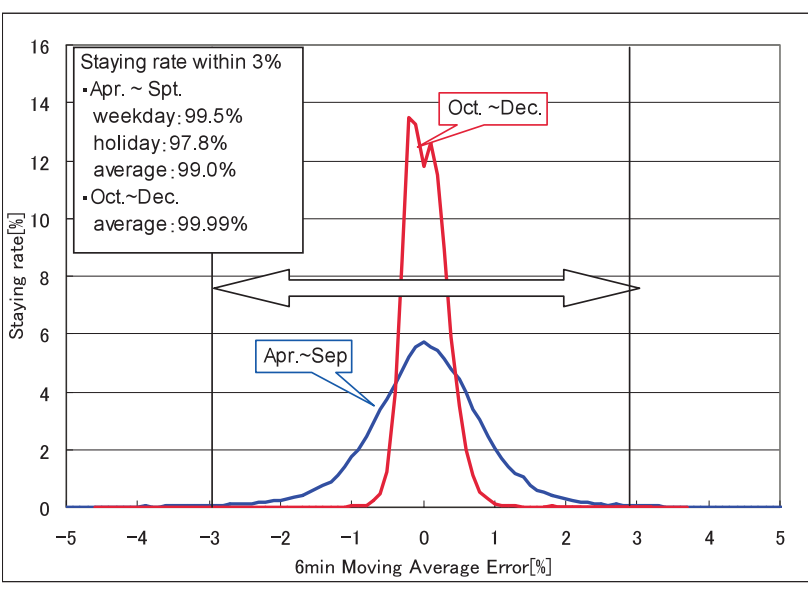

図 9 制御精度の分布

Fig. 9. Histogram of control error. 
給制御が行われる。自動需給制御結果の一例を図 7 に示す。 上から順に蓄電設備蓄電容量 $[\mathrm{kWh}$ （Battery capacity：通 常は設備容量の 60～90\%に相当する 864～1296kWh で運 用), 各発電機出力 $[\mathrm{kW}](\mathrm{GE} 1, \mathrm{GE} 1+2$, Battery, PV+WT) および需要家受電電力合計 $[\mathrm{kW}$ (Demand：自然エネルギー を負の負荷として含む)，6分間移動平均制御 [\%]（Control error）を示している。ガスエンジン 1 台の出力可能範囲は 85 170 kW であるが，図から需要および自然エネルギーの 変動に対して蓄電池の充放電とガスエンジン運転台数を適 切に切り替えながら追従制御し, 買電量を計画值の $5 \mathrm{~kW}$ で一定に制御できている事がわかる。

また，図 8 には図 5(b) に示す休日で太陽光発電が急激に 変動をしている時間帯を拡大表示したものである。急激な 太陽光出力変動に対しては, 連系点電力制御の機能により, 急峻な変動には蓄電池が対応, 緩やかな変動にはガスエン ジンが対応している様子が分かる。

図 9 に 6 分間平均制御誤差の度数分布を示す。ここでは, 2006 年 4 月から 9 月までと, 運用実績に基づき連系点電力 制御に拀ける比例ゲイン，積分ゲインをハンチングが発生 しない範囲で増大させた後の 10 月から 12 月のデータをプ ロットしている。6 分間平均制御誤差の目標精度 3\%に対す る滞在率は，4 月から 9 月は 99.0\%（平日：99.5\%，休日： 97.8\%)，10月以降は 99.99\%であり，目標を達成できてい ることがわかる。

\section{6. 結果の分析}

本章では，マイクログリッドの目的である自然エネルギー 変動の抑制効果の検討を行う。マイクログリッド内の変動 成分は，大きく分けて次の 3 つの要素から構成される。

（1）周期の長い需要変動・自然エネルギー（PV）変動

（2）数分程度の需要変動・自然エネルギー変動

（3）負荷特性による数秒程度の需要変動

このうち，（3）については, 系統全体の規模から見れば変 動周期に相関性はなく大数の法則により平滑化され系統に 与える影響は少ないと考えられる。したがって，(1)，(2) の変動に対する抑制効果でマイクログリッドの需給制御の 効果を評価することが望ましいと考えられる。

そこで，1 秒周期計測データをウェーブレット変換するこ とによりマイクログリッド内の各変動要素を変動周期成分 ごとに分離し分析を行った。図 10 は，12月の日中 8 時か ら 16 時までの各変動成分に関して, 横軸を変動周期 [秒], 縦軸を 2 乗平均変動振幅 $[\mathrm{kW}]$ としてプロットしたもので ある。図中の「Demand+PV」は需要家が自然エネルギー を無対策で導入した際に系統に与える変動，「PV」は自然 エネルギーの変動,「Demand」は PV 導入前の変動,「Controlled」はマイクログリッド化後の変動である。したがっ て「Demand+PV」から「Controlled」を差し引いたものが マイクログリッド導入による需要を含めた変動削減量とな る。さらに, PV 導入後の制御結果「Controlled」から PV 導入前の需要変動分「Demand」を差し引くことで，マイ

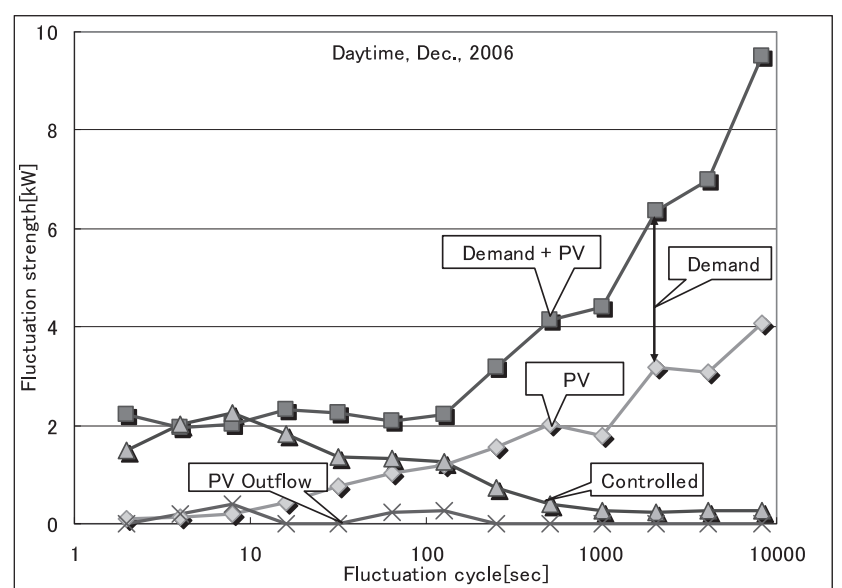

図 10 変動周期毎の変動抑制効果

Fig. 10. Relation between fluctuation cycle and control efficiency.

クログリッド化した PV を導入したことによる変動増加分 $\lceil\mathrm{PV}$ Outflow」(需要変動も抑制している場合は負になるが ここでは０としている）が得られる。

図 10 から，以下のことがわかる。

・本システムにおける自然エネルギー導入量は全需要の 約 $16 \%$ であが，1 分以上の領域では自然変動の影響 が全変動の約 50\%を占める。一方 30 秒以下の領域で はその影響は少ない。したがって，自然エネルギー抑 制マイクログリッドの需給制御としては 1 分以上の変 動成分の抑制が特に重要である。

・本システムでは，マイクログリッド化した自然エネル ギー導入に伴う変動成分の増加（図 8 の PV_Outflow） がほぼ 0 に抑制できている。このことから，マイクロ グリッド化による自然エネルギー変動抑制の効果が確 認できる。

なお，10 秒付近ならびに 100 秒付近で自然エネルギーの 変動が増加している。前者は連系点電力制御で短周期成分 を一次遅れフィルタにより除去していることならびに計測 誤差の影響と考えられる。後者については主として積分制 御を分担するガスエンジンの追従する時間領域で発生して いることから，ガスエンジンの指令值に対する制御不感带 が原因と考えられる。

\section{7. おわりに}

本稿では，「八戸市水の流れを電気で返すプロジェクト」 において開発したマイクログリッドの需給制御について，需 給制御問題構造を階層構造化した制御方式を提案し, 実証 試験実績により目標とした制御性能が得られることを確認 した。また，マイクログリッドの導入の目的である自然エ ネルギー変動抑制に関しては, 各要素の周期成分に着目し た分析を行い, 自然エネルギー流出抑制の効果を確認した。 今後の本プロジェクトでは 2008 年 3 月までの実証期間 で，以下の点について検討を行う予定である。 
（1）長期にわたるデー夕収集により，経済性，効率性 に関する分析

（2）導入設備の一部の運用を抑制することなどで電力 品質と経済性のトレードオフの確認

(3) 系統から切り離した自立運転

最後に，本研究を進めるにあたりご協力・ご支援いただ いた, NEDO 技術開発機構, 三菱総合研究所ならびに八戸 市の方々に感謝の意を表します。

(平成 19 年 1 月 30 日受付, 平成 19 年 7 月 6 日再受付)

1) "Integration of Distributed Energy Resources The CERTS MicroGrid Concept", Consortium for Electric Reliability Technology Solutions (CERTS), LBNL-50829 (2003-10)

(2) T. Goda, Y. Takuma, Y. Izui, Y. Kojima, E. Takeuchi, and K. Takasaka: "Microgrid", ISBN: 4902553074 (2004) (in Japanese)

合田忠弘·田熊良行·泉井良夫 - 小島康弘 ·竹内英次郎 · 高坂 幹 : 「マイクログリッド」, 日本電気協会新聞部 (2004)

(3) K. Takahashi, H. Kita, E. Tanaka, and J. Hasegawa: "A Method for Balancing between Supply and Demand Based on Distributed Autonomous Operation of an Isolated System in FRIENDS", IEEJ Trans. PE, Vol.126, No.10, pp.1039-1048 (2006-10) (in Japanese)

高橋一仙・北 裕幸・田中英一・長谷川淳：「FRIENDS における自 律分散運用に基づく自立系統運転時の需給調整手法」, 電学論 B, 126, 10, pp.1039-1048 (2006-10)

(4) T. Shinji, T. Sekine, A. Akisawa, T. Kashiwagi, G. Fujita, and M. Matsubara: "Discussion on Reduction of Power Fluctuation by Distributed Generation in Micro Grid", IEEJ Trans. PE, Vol.126, No.1, pp.14-20 (2006-1) (in Japanese)

進士誉夫 · 関根剛史 - 秋澤 淳 - 柏木孝夫 - 藤田吾郎 - 松原正芳 : 「分散型電源によるマイクログリッド内の電力変動抑制に関する考 察」, 電学論 B, 126, 1, pp.14-20 (2006-1)

( 5 ) M. Barnes, G. Ventakaramanan, J. Kondoh, R. Lasseter, H. Asano, N. Hatziargyrios, J. Oyarzabal, and T. Green, "Real-World MicroGrids - An Overview", IEEE System of Systems Engineering Symposium (2007)

(6) Y. Fujioka, H. Maejima, S. Nakamura, Y. Kojima, M. Okudera, and S. Uesaka: "Regional power grid with renewable energy resources: A demonstrative project in Hachinohe", CIGRE, C6-305 (2006)

( 7 ) M. Kosho, Y. Kojima, and M. Kataoka: "Control system for Micor-grid supplying heat and electricity", Mitsubishi Electric Giho, Vol.80, No.3 (2006) (in Japanese)

古塩正展・小島康弘・片岡道雄 :「マイクログリッド需給制御システ 厶の開発」, 三菱電機技術報告, 80, No.3 (2006)

(8) Y. Kojima and M. Koshio: "A Demonstrative Research on a Micro-Grid $\sim$ A Online Demand and Supply Control Method for Micro-Grid ", Proc. of 2006 Annual Conference of Power \& Energy Society, IEE Japan (2006) (in Japanese)

小島康弘・古塩正展：「マイクログリッドの実証による検討」, 平成 18 年電気学会 $\mathrm{B}$ 部門大会 (2006)

（9）中村静香：「最急降下法を用いた問題空間の探索一電力系統復旧へ の適用」, 電気学会電力技術研資, PE-91-33 (1991)

(10) K. Temma, Y. Kono, M. Shimomura, M. Kataoka, T. Goda, and S. Uesaka: "Proposal and Development of Power Quality Improvement Method under Islanding Operation in a Micro-Grid", IEEJ Trans. PE, Vol.126, No.10, pp.1032-1038 (2006-10) (in Japanese)

天満耕司 · 河野良之 ·下村 勝 ·片岡道雄 - 合田忠弘 ·上坂 真 : 「マイクログリッドの自立運転時の電力品質維持手法の提案と開発」, 電学論 B, 126, 10, pp.1032-1038 (2006-10)

小 島 康 弘 (上級会員) 1966 年 1 月 10 日生。 1990 年 3 月

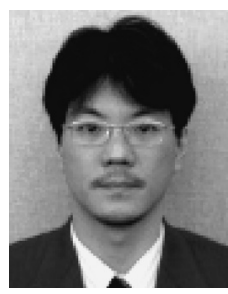
大阪大学大学院工学研究科修士課程修了。同年 4 月, 三菱電機（株）入社。現在, 先端技術総合研 究所にて, 主として電力流通システムをはじめと する社会インフラシステムに対する知的情報処理 技術の適用に関する研究に従事。IEEE 会員。

古 塩 正 展 (正員) 1970 年 2 月 22 日生。 1992 年 3 月筑波

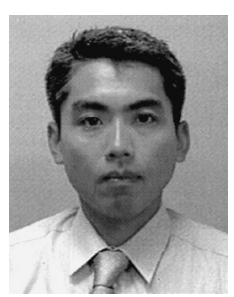
大学第一学群自然学類物理専攻卒業。同年 4 月三 菱電機（株）入社。主として，最適化技術を適用 した電力系統の運用計画・制御システムの開発に 従事。

中 村 静 香

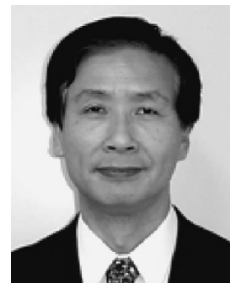

（上級会員） 1949 年 3 月 31 日生。1 1973 年 3 月 成蹊大学大学院工学研究科修士課程修了。同年 4 月三菱電機 (株) 入社。主として, 電力系統への 最適化技術の適用に関する研究・開発に従事, 現 在に至る。工学博士 (東北大学)。1990 年オーム 技術賞。情報処理学会会員。 